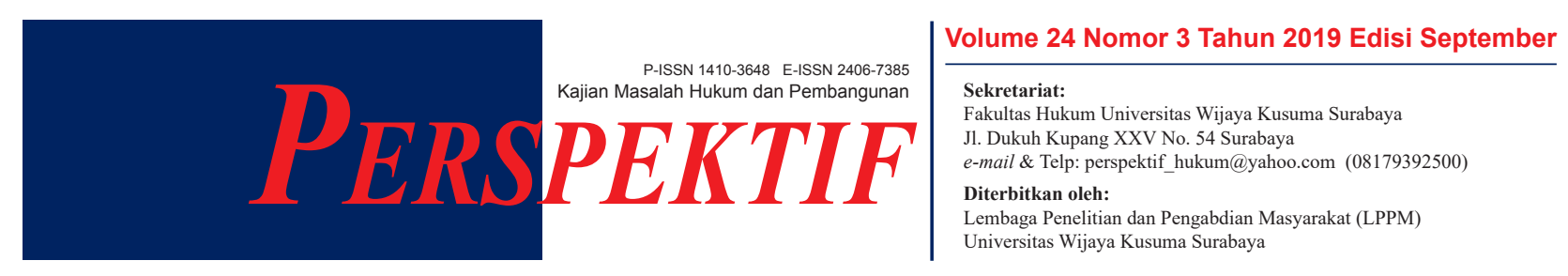

\title{
PENGURUSAN HARTA PAILIT YANG BERSIFAT TERDAFTAR DAN BERJANGKA WAKTU TERTENTU YANG DIMILIKI DEBITOR PERSEROAN TERBATAS
}

\author{
Adri Naufal Saniy \\ Fakultas Hukum, Universitas Airlangga \\ e-mail: adrinaufals@gmail.com \\ Rr. Pratiwi Kusuma Dyah Asri \\ Fakultas Hukum, Universitas Airlangga \\ e-mail: rrpratiwikusuma@gmail.com
}

\begin{abstract}
ABSTRAK
Kewenangan kurator dalam hal pengurusan berupa perpanjangan benda terdaftar dan berjangka waktu tertentu yang habis jangka waktunya dalam harta pailit milik Perseroan Terbatas serta perlindungan hukum terhadap para pihak yang terkait dengan benda terdaftar dan berjangka waktu tertentu yang habis jangka waktunya dalam harta pailit milik Perseroan Terbatas dalam hukum kepailitan. Artikel ini menggunakan metode penelitian yuridis normatif. Hasil penelitian menunjukkan bahwa kurator menjadi pihak yang paling berwenang berdasarkan kewenangan luasnya sebagaimana diatur dalam Pasal 6 ayat (1) jo. Pasal 69 ayat (1) UU K-PKPU dalam hal pengurusan berupa perpanjangan benda terdaftar dan berjangka waktu tertentu yang habis jangka waktunya dalam harta pailit milik Perseroan Terbatas. Selain itu hasil penelitian juga menunjukkan bahwa perlindungan hukum terhadap hak kreditor terhadap benda terdaftar dan berjangka waktu tertentu yang habis jangka waktunya dalam harta pailit milik Perseroan Terbatas dilakukan oleh kurator dalam hal perpanjangannya sesuai prosedur dan dimungkinkan adanya gugatan Perbuatan Melanggar Hukum (PMH) terhadap debitor apabila ada unsur kesengajaan karena tidak melakukan perpanjangan benda terdaftar dan berjangka waktu tertentu yang habis jangka waktunya dalam harta pailit sebelum adanya putusan permohonan pernyataan pailit.
\end{abstract}

Kata Kunci: Kepailitan; Perseroan Terbatas; Benda Terdaftar Berjangka Waktu Tertentu

ABSTRACT

This article analyze the authority of Curators on the matter of Bankruptcy Management which includes registered objects and time limited Object that already expired included in the Limited Liability Company (LLC) Bankruptcy Estate also the Legal Protection of related parties on said object in the scope of Bankruptcy Law. This journal uses juridical normative research method. The result of this research shows that curators became the most authorized party based on their broad authority as regulated in Act Number 37 Year 2007 About Kepailitan dan Penundaan Kewajiban Pembayaran Utang Paragraph 16 Article 1 jo. Paragraph 69 Article 1 especially concerning the management of registered objects and time limited Object that already expired included in the Limited Liability Company (LLC) Bankruptcy Estate. In addition research also suggest that legal protection of creditor rights to registered objects and time limited Object that already expired included in the Limited Liability Company (LLC) Bankruptcy Estate is done by the curators in terms of the procedure for time extensions and tort lawsuit against the debtors in case there are intention to intentionally not extend the time limit for egistered objects and time limited Object that already expired included in the Bankruptcy Estate before the verdict to bankruptcy solicitation statement.

Keywords: Bankruptcy; Limited Liability Company; Registered object time limited object 


\section{PENDAHULUAN}

Mendasarkan pada BW, pada prinsipnya tidak ada utang tanpa adanya agunan (jaminan), hal ini sebagaimana redaksi Pasal 1131 BW yang menegaskan bahwa segala kebendaan baik yang bergerak, tidak bergerak, sudah ada, dan masih akan ada, dijadikan jaminan bagi pelunasan suatu perikatan seseorang. Artinya, walaupun seseorang tidak menjaminkan suatu hal apapun dalam perjanjian utang-piutangnya, hukum senantiasa akan tetap melindungi pihak kreditor apabila pihak debitor cidera janji, dengan cara semua barang milik debitor dilakukan penyitaan dan penjualan untuk melunasi utangnya, hal ini dinamakan jaminan umum. Kendati demikian, hanya dengan memanfaatkan jaminan umum, kedudukan kreditor tetap sangat beresiko, karena dalam jaminan umum terkandung prinsip Paritas Creditorium. ${ }^{1}$ Oleh karenanya penyelesaian utang-piutang yang difasilitasi oleh negara dalam bentuk kepailitan, lebih banyak digunakan oleh para pihak yang bersengketa, dengan mengingat keunggulan-keunggulannya. Tidak terlepas suatu Perseroan Terbatas, itu juga dapat dimohonkan pailit.

Dalam hal Perseroan Terbatas (selanjutnya disebut PT) dimohonkan pailit oleh para kreditornya dan dikarenakan telah memenuhi syarat berdasarkan Undang-Undang Nomor 37 Tahun 2004 tentang Kepailitan dan Penundaan Kewajiban Pembayaran Utang (selanjutnya disebut UU K-PKPU) maka pengadilan niaga pada pengadilan negeri tempat memeriksa dan mengadili perusahaan tersebut, menjatuhkan putusan atas permohonan pernyataan pailit terhadap perusahaan tersebut. Sebuah PT yang dimohonkan pernyataan pailit bertujuan agar PT dinyatakan pailit, karena pailit merupakan suatu keadaan dimana debitor tidak mampu untuk melakukan pembayaran-pembayaran terhadap utangutang dari para kreditornya dengan kondisi kesulitan keuangan (financial distress) dari usaha debitor yang telah mengalami kemunduran yang menyebabkan debitor tidak mampu membayar hutangnya kepada para kreditornya. ${ }^{2}$ Definisi kepailitan sebagaimana dianyatakan dalam Pasal 1 angka 1 UU K-PKPU

\footnotetext{
${ }^{1}$ Fani Martiawan. (2014). "Eksistensi Kreditor Separatis Sebagai Pemohon Dalam Perkara Kepailitan". Jurnal Perspektif. Volume XIX Nomor 1 Edisi Januari Tahun 2014. Surabaya: Universitas Wijaya Kusuma Surabaya, h. 6.

${ }^{2}$ Hadi Subhan. (2012). Hukum Kepailitan: Prinsip, Norma, dan Praktik di Pengadilan. Jakarta: Kencana, h. 1.
}

bahwa Kepailitan adalah sita umum atas semua kekayaan debitor pailit yang pengurusan dan pemberesannya dilakukan oleh kurator di bawah pengawasan hakim pengawas sebagaimana diatur dalam undang-undang ini.

Akibat putusan permohonan pernyataan pailit sebagaimana dinyatakan dalam Pasal 15 ayat (1) UU K-PKPU bahwa "Dalam putusan permohonan pernyataan pailit, harus diangkat kurator dan seorang hakim pengawas yang ditunjuk dari hakim pengadilan" melalui penetapan pengadilan. Dengan adanya putusan permohonan pernyataan pailit dan penetapan ketua pengadilan tentang pengangkatan kurator dan hakim pengawas, maka sejak saat itu kewenangan debitor untuk mengurus harta perusahaannya beralih menjadi kewenangan kurator yang diawasi oleh hakim pengawas. Satusatunya yang dapat menjadi kurator dalam kepailitan adalah balai harta peninggalan dan dengan adanya pembaharuan UU K-PKPU, selain balai harta peninggalan, kurator swasta juga dimungkinkan untuk mengurus harta pailit. ${ }^{3}$ Tugas dan kewenangan kurator dalam hal Pengurus harta Pailit antara lain:

1) Sebagaimana diatur dalam Pasal 15 ayat (4) UU K-PKPU dalam jangka waktu 5 (lima) hari setelah tanggal putusan pernyataan pailit diterima oleh Kurator dan Hakim Pengawas, Kurator mengumumkan dalam Berita Negara Republik Indonesia dan paling sedikit 2 (dua) surat kabar harian yang ditetapkan oleh Hakim Pengawas, mengenai iktisar putusan pernyataan pailit yang memuat hal-hal sebagai berikut:

a) Nama, alamat dan pekerjaan debitor;

b) Nama Hakim Pengawas;

c) Nama, alamat dan pekerjaan kurator;

d) Nama, alamat dan pekerjaan Panitia Kreditor sementara apabila telah ditunjuk;

e) Tempat dan waktu penyelenggaraan rapat pertama kreditor.

2) Sebagaimana Pasal 86 ayat (3) UU K-PKPU, Kurator memberitahukan kepada kreditor dengan surat tercatat atau kurir paling lambat 5 (lima) hari sejak putusan pernyataan pailit ditetapkan tentang rencana rapat kreditor pertama.

3) Sebagaimana diatur dalam Pasal 98 UU K-PKPU bahwa Kurator mengamankan harta pailit dan

\footnotetext{
3 ibid, h. 134.
} 
penyimpanan semua surat, uang, perhiasan, dan surat berharga lainnya dengan memberikan tanda terimanya.

Harta Kepailitan diatur secara tersirat sebagaimana dimaksud dalam Pasal 21 UU K-PKPU yang dinyatakan bahwa Kepailitan meliputi seluruh kekayaan Debitor pada saat putusan pernyataan pailit diucapkan serta segala sesuatu yang diperoleh selama kepailitan. Berdasarkan isi Pasal tersebut yang dimaksud harta kepailitan adalah segala sesuatu atau harta yang didapat selama berlangsungnya kepailitan. Harta kepailitan banyak macamnya, salah satunya adalah berupa benda yang dimiliki oleh debitor pailit. Jenis-jenis benda sebagaimana diatur dalam Pasal 504 Burgerlijk Wetboek (selanjutnya disebut BW) yang dinyatakan bahwa tiap-tiap kebendaan adalah bergerak atau tidak bergerak, satu sama lain menurut ketentuan-ketentuan dalam kedua bagian berikut. Dari aturan tersebut dapat diambil kesimpulan bahwa harta kekayaan berupa benda terbagi menjadi 2 yaitu benda bergerak dan tidak bergerak. Pembagian benda bergerak dan benda tidak bergerak diatur dalam buku kedua BW tentang kebendaan. Benda bergerak diatur didalam Pasal 509 BW, sedangkan benda tidak bergerak diatur didalam Pasal 506-508 BW yang tidak menjelaskan mengenai definisi dengan jelas benda tidak bergerak.

Hakikat benda adalah segala sesuatu yang dapat "diakui" atau dapat diberikan hak milik atas benda tersebut kepada perseorangan atau badan hukum. Dengan pengertian demikian dapat diartikan bahwa benda merupakan obyek di dalam hukum. Namun terdapat beberapa pandangan lain tentang benda yang menyatakan benda adalah barang yang dapat terlihat saja ataupun benda merupakan harta kekayaan seseorang. Bilamana benda diartikan sebagai kekayaan seseorang, maka barang-barang yang tak tampak misalnya, hak-hak dengan contoh hak piutang atau penagihan juga disebut sebagai benda. Seperti pada seseorang yang telah menggadaikan atau menjual barang-barang yang tampak maka orang itu juga dapat menggadaikan atau menjual hak-hak yang dimilikinya. Undang-undang membagi bendabenda dalam beberapa macam, yakni: ${ }^{4}$

1. Benda yang dapat diganti (contohnya uang) dan yang tak dapat diganti (contohnya seekor kuda).

\footnotetext{
${ }^{4}$ Subekti. (2003). Pokok-Pokok Hukum Perdata. Jakarta: Intermasa, h. 61.
}

2. Benda yang dapat diperdagangkan (praktis tiap barang dapat diperdagangkan) dan yang tidak dapat diperdagangkan atau "di luar perdagangan" (contohnya jalan-jalan dan lapangan umum)

3. Benda yang dapat dibagi (contohnya beras) dan yang tidak dapat dibagi (contohnya seekor kuda).

4. Benda yang bergerak (contohnya perabot rumah) dan yang tidak bergerak (contohnya tanah).

Benda bergerak juga terdiri dari benda bergerak terdaftar yang memiliki jangka waktu tertentu dan benda bergerak tidak terdaftar. Harta kekayaan berupa benda bergerak terdaftar dan berjangka waktu yang dapat diartikan bahwa suatu benda yang terdaftar berdasarkan peraturan perundang-undangan yang berlaku dan memiliki jangka waktu tertentu sebagaiamana yang telah diatur dalam peraturan perundang-undangan di Indonesia, sebagai contoh benda bergerak terdaftar dan berjangka waktu adalah sebagai berikut:

1. Obligasi dan/atau Surat Utang Negara sebagaimana Pasal 511 angka 5 BW;

2. Surat Tanda Nomor Kendaraan Bermotor sebagaimana diatur dalam Undang-Undang Perpajakan dan Undang-Undang Nomor 22 Tahun 2009 tentang Lalu Lintas dan Angkutan Jalan;

3. Saham, deposito, bilyet, giro, wesel, dan cek sebagaimana diatur dalam Pasal 511 angka 4 BW, Kitab Undang-Undang Hukum Dagang (selanjutnya disebut KUHD) dan UndangUndang Nomor 7 Tahun 1992 tentang Perbankan jo. Undang-Undang Nomor 10 Tahun 1998 tentang Perubahan atas Undang-Undang Nomor 7 Tahun 1992 tentang Perbankan (selanjutnya disebut UU Perbankan).

Selain benda bergerak terdaftar dan berjangka waktu, terdapat pula jenis benda bergerak terdaftar yang tidak berjangka waktu yaitu sebagai contohnya adalah bunga dalam hukum perdata sebagaimana diatur dalam Pasal 511 angka 2 BW. Dari pembagian mengenai sifat dari ada atau tidaknya jangka waktu benda bergerak terdaftar dalam kepailitan berkaitan dengan kewenangan kurator.

Dimana didalam hal kepengurusan harta pailit yang tergolong sebagai benda bergerak terdaftar dan berjangka waktu, tetapi pada saat setelah putusan permohonan pernyataan pailit oleh Pengadilan, jangka waktu dari benda tersebut telah jatuh tempo, 
menjadi permasalahan baru berkaitan dengan kewenangan kurator untuk melakukan pembaharuan terhadap harta debitor pailit yang telah jatuh waktu tersebut. Ditinjau dari UU K-PKPU kewenangan kurator untuk memperbaharui harta debitor yang telah jatuh waktu tersebut tidak diatur secara eksplisit, jadi manakala kurator melakukan pengurusan terhadap harta debitor sebagaimana disebutkan sebelumnya tidak mempunyai Legal Standing.

\section{PERUMUSAN MASALAH}

Pengurusan harta pailit yang bersifat terdaftar dan berjangka waktu tertentu yang dimiliki debitor Perseroan Terbatas.

\section{PEMBAHASAN}

\section{Kurator Beserta Kewenangannya}

Sejak putusan permohonan pernyataan pailit ditetapkan, debitor pailit tidak lagi diperkenankan untuk melakukan pengurusan atas harta pailit sebagaimana diatur dalam Pasal 24 UU K-PKPU. Pengurusan dan pemberesan harta pailit tersebut menjadi kewenangan Kurator dengan diawasi oleh Hakim Pengawas yang ditunjuk oleh Pengadilan Niaga. Kurator dapat ditunjuk menjadi seorang kurator untuk mengurus dan membereskan harta pailit dalam kepailitan sebagaimana dinyatakan dalam Pasal 15 ayat (3) UU K-PKPU bahwa kurator yang diangkat sebagaimana dimaksud pada ayat (1) harus independen, tidak mempunyai benturan kepentingan dengan Debitor atau Kreditor, dan tidak sedang menangani perkara kepailitan dan penundaan kewajiban pembayaran utang lebih dari 3 (tiga) perkara. Jenis kurator yang berupa kurator lainnya sebagaimana dinyatakan dalam Pasal 70 UU K-PKPU bahwa Kurator yang bukan atau selain Balai Harta Peninggalan adalah orang perseorangan yang wajib memenuhi syarat-syarat tertentu, yaitu:

a. orang perseorangan yang berdomisili di Indonesia, yang memiliki keahlian khusus yang dibutuhkan dalam rangka mengurus dan/atau membereskan harta pailit; dan

b. terdaftar pada kementerian yang lingkup tugas dan tanggungjawabnya dibidang hukum dan peraturan perundang-undangan.

Dalam menjalankan tugasnya sebagai kurator yang mengelola harta pailit wajib independen artinya kurator yang diangkat tidak ada kepentingan baik langsung maupun tidak langsung terhadap harta pailit. Apabila debitor atau kreditor tidak mengajukan usul pengangkatan kurator ke Pengadilan, maka BHP bertindak sebagai kurator. Apabila yang diangkat sebagai kurator bukan dari BHP, maka kurator tersebut wajib bersifat independen dan tidak mempunyai benturan kepentingan dengan pihak manapun baik debitor maupun kreditor. Sutan Remy Sjahdeini lebih lanjut menjelaskan secara eksplisit bahwa telah terjadi benturan kepentingan apabila sebagai berikut, antara lain: ${ }^{5}$

a. Kurator menjadi salah satu kreditor;

b. Kurator memiliki hubungan kekeluargaan dengan pemegang saham pengendali atau pengurus dari perseroan debitor;

c. Kurator memiliki saham lebih dari 10\% (sepuluh persen) pada salah satu perusahaan kreditor atau pada perseroan debitor;

d. Kutaror adalah pegawai, anggota direksi, atau anggota komisaris dari salah satu perusahaan kreditor atau dari perusahaan debitor.

Yang dimaksud kewenangan kurator dalam hal pemberesan harta pailit milik debitor, adalah meliputi hal-hal berikut:

a. Menjual semua benda debitor pailit secara lelang atau di bawah tangan dengan ijin Hakim Pengawas sebagaimana dinyatakan dalam Pasal 185 UU K-PKPU;

b. Menyusun daftar pembagian harta untuk dimintakan persetujuan Hakim Pengawas dan mengumumkan daftar pembagian tersebut dalam surat kabar sebagaimana dinyatakan dalam Pasal 189 jo. Pasal 192 ayat (2) UU K-PKPU;

c. Melaksanakan pembagian sesuai daftar pembagian yaitu dengan melakukan pembayaran sesuai daftar pembagian, setelah tenggang waktu sebagaimana dimaksud Pasal 192 UU K-PKPUatau setelah diajukan perlawanan dan ada keputusan untuk itu sebagaimana dinyatakan dalam Pasal 201 UU K-PKPU;

d. Setelah dilakukan pembayaran maka Kurator melakukan pengumuman berkahirnya kepailitan dalam Berita Negara Republik Indonesia dan surat kabar sebagaimana dimaksud dalam Pasal 15 ayat (4) jo. Pasal 202 ayat (2) UU K-PKPU;

${ }^{5}$ Sutan Remy Sjahdeini. (2010). Hukum Kepailitan: Memahami Undang-Undang No. 37 Tahun 2004 Tentang Kepailitan. Jakarta: Pustaka Utama Grafiti, h. 209. 
e. Memberikan pertanggungjawaban mengenai pengurusan dan pemberesan harta pailit yang telah dilakukannya kepada Hakim Pengawas paling lama 30 (tiga puluh) hari setelah berakhirnya kepailitan sebagaimana dinyatakan dalam Pasal 202 ayat (3) UU K-PKPU.

\section{Pengelompokan Harta Debitor Pailit}

Harta Kepailitan diatur secara tersirat dalam Pasal 21 UU K-PKPU yang berisi, "Kepailitan meliputi seluruh kekayaan Debitor pada saat putusan pernyataan pailit diucapkan serta segala sesuatu yang diperoleh selama kepailitan". Menurut Sutan Remy Sjahdeini dalam buku yang berjudul "Hukum Kepailitan: Memahami Undang-Undang Nomor 37 Tahun 2004", ketentuan Pasal 21 UU K-PKPU tersebut merupakan pelaksanaan dari UndangUndang, dan oleh karena itu sejalan dengan ketentuan Pasal 1131 BW. Sebagaimana dinyatakan dalam Pasal 1131 BW bahwa seluruh harta kekayaan debitor baik yang bergerak maupun yang tidak bergerak, baik yang sudah ada maupun yang baru akan ada dikemudian hari, menjadi tanggungan (agunan) bagi seluruh utang debitor. Berdasarkan Pasal tersebut yang dimaksud harta kepailitan adalah segala sesuatu atau harta yang didapat selama berlangsungnya kepailitan. Harta kepailitan banyak macamnya, dapat berupa benda bergerak maupun benda tidak dapat bergerak. Sebagaimana dinyatakan dalam Pasal 504 BW bahwa tiap-tiap kebendaan adalah bergerak atau tidak bergerak, satu sama lain menurut ketentuanketentuan dalam kedua bagian berikut. Dari aturan tersebut dapat diambil kesimpulan bahwa harta kekayaan berupa benda terbagi menjadi 2 (dua) yaitu benda bergerak dan tidak bergerak.

Pembagian benda dalam buku ke dua tentang kebendaan BW mengenai benda bergerak diatur didalam Pasal 509 BW bahwa kebendaan bergerak karena sifatnya ialah kebendaan yang dapat berpindah atau dipindahkan. Benda bergerak juga terdiri dari benda bergerak terdaftar yang memiliki jangka waktu tertentu dan benda bergerak tidak terdaftar. Contoh dari harta kekayaan yang tergolong sebagai benda bergerak ialah:

1. Benda bergerak terdaftar yaitu Hak pakai hasil dan hak pakai atas kebendaan bergerak, kendaraan bermotor, kapal, perahu, perahu tambang, gilingan, dan sejenisnya;
2. Benda bergerak tidak terdaftar yaitu Bunga dalam hukum perdata;

3. Benda bergerak tidak berwujud terdaftar yaitu Saham, Deposito, Bilyet Giro, Wesel, Cek, Obligasi, Surat Utang Negara dan Obligasi asing. Dalam Buku Kedua BW tentang kebendaan pada Pasal 506 BW sampai dengan Pasal 508 BW tidak dijelaskan mengenai definisi jelasnya benda tidak bergerak. Subekti menjelaskan bahwa definisi benda tidak bergerak adalah suatu benda dapat tergolong dalam golongan benda yang tidak bergerak ("onroerend") pertama karena sifatnya, kedua karena tujuan pemakaiannya, dan ketiga karena memang demikian ditentukan oleh undang-undang. ${ }^{6}$ Dari definisi tersebut surat berharga dapat diketahui melalui benda yang memenuhi karakteristik seperti yang disampaikan Subekti secara alternatif. Contoh dari harta kekayaan yang tergolong sebagai benda tidak bergerak ialah:

1. Benda tidak bergerak karena sifatnya ialah Pekarangan atau Tanah, bangunan diatasnya, penggilingan, hasil kebun, kayu tebangan, pipa dan got untuk pengairan yang ada di pekarangan;

2. Benda tidak bergerak tujuan atau peruntukkan pemakaiannya ialah Peralatan pabrik, peralatan rumah, peralatan diatas tanah kosong, dan bahan bangunan;

3. Benda tidak bergerak karena ketentuan undangundang ialah hak pakai hasil atau atas kebendaan tidak bergerak, hak pengabdian tanah, hak numpang-karang, hak usaha, bunga tanah, bunga sepersepuluh, pajak pekan atau pasar, gugatan revindikasi benda tidak bergerak.

\section{Kewenangan Kurator Terhadap Harta Debitor Pailit yang Habis Jangka Waktunya}

Harta debitor pailit yang yang telah habis jangka waktunya seringkali tidak dilakukan pengurusan perpanjangan atau pembaharuan oleh debitor pailit, dikarenakan debitor merasa tidak memiliki hak lagi untuk menguasai dan mengurus kekayaannya yang termasuk dalam harta pailit sejak tanggal putusan pernyataan pailit diucapkan. ${ }^{7}$ Sebab debitor yang

\footnotetext{
${ }^{6}$ Subekti. (2003). op.cit., h. 61-62.

${ }^{7}$ Undang-Undang Nomor 37 Tahun 2004 tentang Kepailitan dan Penundaan Kewajiban Pembayaran Utang, (Lembaran Negara Nomor 131 Tahun 2004, Tambahan Lembaran Negara Nomor 4443), Pasal 24 ayat (1).
} 
dinyatakan pailit berdasar permohonan pernyataan pailit yang dijatuhkan oleh pengadilan tidak melakukan pengurusan pada harta debitor yang habis jangka waktunya dapat disengaja maupun tidak jika dilihat dari ketentuan di UU K-PKPU. Harta debitor pailit yang yang telah habis jangka waktunya yang tidak dilakukan pengurusan untuk perpanjangan atau pembaharuan seringkali berakibat berkurangnya jumlah harta debitor pailit, berkurangnya nilai ekonomi suatu benda dan hilangnya status hak dari penghitungan awal seorang kurator. ${ }^{8}$ Hal tersebut justru merugikan hak para kreditor. Harta debitor pailit yang telah habis jangka waktunya berupa benda bergerak terdaftar berjangka waktu tertentu dan benda tidak bergerak berjangka waktu tertentu sebagaimana telah disampaikan pada sub bab sebelumnya.

Kewenangan kurator untuk mengurus harta debitor pailit yang telah habis jangka waktunya secara implisit dalam dua pasal di UU K-PKPU. Pertama dalam Pasal 69 ayat (1) UU K-PKPU bahwa Tugas kurator adalah melakukan pengurusan dan/atau pemberesan harta pailit. Berikutnya dapat diartikan dengan mengamankan harta debitor pailit agar tidak berkurang jumlahnya dan kualitasnya sebagaimana dinyatakan dalam Pasal 98 UU K-PKPU bahwa sejak dimulai pengangkatannya, kurator harus melaksanakan semua upaya untuk mengamankan harta pailit dan menyimpan semua surat, dokumen, uang, perhiasan, efek, dan surat berharga lainnya dengan memberikan tanda terima. Tetapi jika ada harta debitor pailit yang telah habis jangka waktunya dengan sengaja oleh debitor yang beriktikad buruk tidak dilakukan pengurusan untuk perpanjangan atau pembaharuan, seyogyanya pula diatur sanksi tegas kepada si debitor yang beriktikad buruk tersebut didalam UU K-PKPU demi kepastian hukum.

\section{Bentuk Perlindungan Hukum Terhadap Harta Pailit Oleh Kurator}

Harta Pailit diatur secara tersirat dalam Pasal 21 UU K-PKPU yang berisi, "Kepailitan meliputi seluruh kekayaan Debitor pada saat putusan pernyataan pailit diucapkan serta segala sesuatu yang diperoleh selama kepailitan". Menurut Sutan

${ }^{8}$ Undang-Undang Nomor 37 Tahun 2004 tentang Kepailitan dan Penundaan Kewajiban Pembayaran Utang, (Lembaran Negara Nomor 131 Tahun 2004, Tambahan Lembaran Negara Nomor 4443), Pasal 100, Pasal 101 dan Pasal 118.
Remy Sjahdeini, yang dimaksud dengan "selama berlangsungnya kepailitan" adalah sejak putusan pailit diucapkan oleh majelis hakim pengadilan niaga sampai dengan selesainya indakan pemberesan dan likuidasi oleh kurator sepanjang putusan pengadilan niaga tersebut tidak diubah sebagai akibat upaya hukum berupa kasasi atau peninjauan kembali. ${ }^{9}$ Pasal 21 UU K-PKPU merupakan bentuk tindak lanjut dari Pasal 1131 BW. Sebagaimana diketahui, menurut ketentuan Pasal 1131 BW seluruh harta kekayaan debitor baik yang bergerak maupun yang tidak bergerak, baik yang sudah ada maupun yang baru akan ada dikemudian hari, menjadi tanggungan (agunan) bagi seluruh utang debitor. ${ }^{10}$ Berdasarkan pasal tersebut yang dimaksud harta pailit adalah segala sesuatu atau harta yang didapat selama berlangsungnya kepailitan.

Harta Pailit yang berasal dari debitor yang telah dinyatakan pailit oleh pengadilan niaga berdasar permohonan pernyataan pailit, apabila habis jangka waktunya pada saat setelah permohonan pernyataan pailit ditetapkan oleh pengadilan niaga juga termasuk kedalam harta pailit ataukah tidak. Sedangkan harta pailit merupakan segala sesuatu atau harta yang didapat selama berlangsungnya kepailitan jika dilihat dari uraian sebelumnya.

Perlu diketahui harta pailit yang habis jangka waktunya pada saat setelah putusan permohonan pernyataan pailit diucapkan oleh majelis hakim pengadilan niaga, termasuk wewenang kurator untuk mengurus harta pailit tersebut atau tidak. Dilihat dari UU K-PKPU, maka kewenangan untuk mengurus harta pailit yang habis jangka waktunya dapat dipahami dari kewenangan seorang kurator secara luas untuk mengurus dan malakukan pemberesan setelah adanya putusan permohonan pernyataan pailit. ${ }^{11}$ Mengingat harta pailit yang habis jangka waktunya dapat berakibat hukum yaitu hilangnya hak atas kebendaannya dan berpengaruh pada nilai ekonomi suatu benda yang tidak maksimal. Harta pailit yang habis jangka waktunya tersebut jika dilakukan pengurusan perpanjangannya/pendaftaran

\footnotetext{
${ }^{9}$ Sutan Remy Sjahdeini. op.cit., h. 179.

${ }^{10}$ ibid., h. 180.

11 Undang-Undang Nomor 37 Tahun 2004 tentang Kepailitan dan Penundaan Kewajiban Pembayaran Utang (Lembaran Negara Tahun 2004 Nomor 131, tambahan Lembaran Negara 4443), Psl. 16 ayat (1) jo. Psl. 69 ayat (1).
} 
ulangnya oleh kurator termasuk sebuah bentuk perlindungan hukum.

Wewenang kurator yang diatur dalam UU K-PKPU secara garis besar adalah melakukan tugas pengurusan dan pemberesan harta pailit. ${ }^{12}$ Kurator menjadi satu-satunya pihak yang berwenang untuk mengamankan harta pailit agar tidak sampai hilang hak atas kebendaannya dan berkurangnya nilai ekonomi suatu benda sejak putusan permohonan pernyataan pailit dijatuhkan.

\section{Pengalihan Hak Terhadap Harta Debitor Pailit}

Kewenangan secara luas yang dimiliki oleh kurator diatur dalam Pasal 16 ayat (1) jo. Pasal 69 Ayat (1) UU K-PKPU, sebagaimana dinyatakan dalam Pasal 16 ayat (1) UU K-PKPU yang berbunyi, "Kurator berwenang melaksanakan tugas pengurusan dan/atau pemberesan atas harta pailit sejak tanggal putusan pailit diucapkan meskipun terhadap putusan tersebut diajukan kasasi atau peninjauan kembali.", dan sebagaimana dinyatakan dalam Pasal 69 ayat (1) UU K-PKPU yang berbunyi, "Tugas Kurator adalah melakukan pengurusan dan/atau pemberesan harta pailit.". Berdasarkan pengaturan dalam pasalpasal tersebut terdapat kewenangan kurator dalam melakukan pemberesan terhadap harta pailit. Sutan Remy Sjahdeini mengungkapkan kondisi insolvensi untuk dapat dilakukan pemberesan oleh kurator sebagaimana dinyatakan dalam Pasal 178 ayat (1) UU K-PKPU, "Jika dalam rapat pencocokan piutang (yaitu rapat verifikasi utang piutang) tidak ditawarkan rencana perdamaian (oleh debitor), atau rencana perdamaian yang ditawarkan tidak diterima oleh rapat, atau pengesahan perdamaian ditolak berdasarkan putusan pengadilan niaga yang telah memperoleh kekuatan hukum tetap, maka demi hukum harta pailit berada dalam keadaan insolvensi (tidak mampu membayar utang-utang debitor)."13

Pengertian pemberesan oleh kurator sebagaimana dinyatakan dalam Penjelasan Pasal 16 ayat (1) UU K-PKPU bahwa yang dimaksud dengan pemberesan dalam ketentuan ini adalah penguangan aktiva untuk membayar atau melunasi utang. Bentuk pemberesan

12 Undang-Undang Nomor 37 Tahun 2004 tentang Kepailitan dan Penundaan Kewajiban Pembayaran Utang (Lembaran Negara Tahun 2004 Nomor 131, tambahan Lembaran Negara 4443), Psl. 16 ayat (1) jo. Psl. 69 ayat (1).

${ }^{13}$ Sutan Remy Sjahdeini. op.cit., h. 279. oleh kurator berupa pemberesan dengan memulai menjual semua harta pailit tanpa perlu mendapat persetujuan dari atau bantuan dari debitor. ${ }^{14}$ Penjualan yang dilakukan oleh kurator terhadap harta pailit milik debitor termasuk pengalihan hak kebendaan dengan bentuk penjualan atas semua benda mengingat ketentuan Pasal 183 ayat (2) dan ayat (3) UU K-PKPU, sebagaimana dinyatakan dalam Pasal 185 ayat (1) UU K-PKPU bahwa semua benda harus dijual dimuka umum sesuai dengan tata cara yang ditentukan dalam peraturan perundangundangan, dalam hal ini berbentuk lelang. ${ }^{15}$ Lelang yang dilakukan tidak tercapai maka kurator dapat melakukan sebagaimana dinyatakan dalam Pasal 185 ayat (2) UU K-PKPU.

\section{PENUTUP \\ Kesimpulan}

Pihak yang memiliki kewenangan untuk melakukan pengurusan perpanjangan hak terhadap harta pailit debitor bukanlah debitor, karena debitor tidak dapat melakukan pengurusan perpanjangan karena demi hukum haknya untuk melakukan pengurusan telah hapus setelah adanya putusan permohonan pernyataan pailit sebagaimana diatur Pasal 24 ayat (1) UUK-PKPU. Kurator terbukti menjadi pihak yang berwenang melakukan pengurusan perpanjangan hak atas benda yang habis jangka waktunya karena merupakan kewenangan yang diartikan secara luas bahwa kurator berwenang melakukan pengurusan dan pemberesan harta pailit sebagaimana diatur dalam Pasal 16 ayat (1) jo. Pasal 69 ayat (1) UU K-PKPU.

Perlindungan hukum kreditor terhadap harta benda debitor yang habis jangka waktunya dilakukan terbukti dilakukan oleh seorang kurator. Bentuk perlindungan hukum yang dapat diberikan oleh kurator adalah dengan melakukan pengurusan harta pailit yang habis jangka waktunya karena merupakan kewenangan secara umum seorang kurator untuk melakukan pengurusan dan pembersan harta pailit sebagaimana diatur dalam Pasal 16 ayat (1) jo. Pasal 69 ayat (1) UU K-PKPU. Perlindungan

14 Undang-Undang Nomor 37 Tahun 2004 tentang Kepailitan dan Penundaan Kewajiban Pembayaran Utang (Lembaran Negara Tahun 2004 Nomor 131, tambahan Lembaran Negara 4443), Psl. 184 ayat (1).

${ }^{15}$ Sutan Remy Sjahdeini, op.cit., h. 280. 
hukum tersebut tidak hanya bagi kreditor tetapi juga bagi debitor dan kurator agar harta pailit tidak sampai hilang hak atas kebendaannya dan dapat mencapai nilai maksimal untuk dijual oleh kurator. Bentuk perlindungan hukum yang diberikan oleh kurator berdasarkan asas iktikad baik dari kurator, perlindungan hukum dan kepastian hukum.

\section{Rekomendasi}

Hukum kepailitan yang hadir dengan peraturan saat ini yaitu UU K-PKPU, mengatur sangat banyak hal hingga ratusan Pasal, akan tetapi, dalam perkembangan hukum, dan temuan-temuan baru, sudah barang tentu sedikit demi sedikit akan terdapat beberapa hal yang tidak sesuai untuk dipraktikkan, prakteknya, oleh karena itu diperlukan kejelian dan kemampuan penafsiran bagi para akademisi ataupun praktisi dalam menerapkan aturan UU K-PKPU astas suatu perkara kepailitan.

\section{DAFTAR PUSTAKA \\ Peraturan Perundang-undangan:}

Undang-Undang Nomor 37 Tahun 2004 tentang Kepailitan dan Penundaan Kewajiban Pembayaran Utang. Lembaran Negara Tahun 2004 Nomor 131, Tambahan Lembaran Negara Nomor 4443.

\section{Buku:}

Hadi Subhan. (2012). Hukum Kepailitan: Prinsip, Norma, dan Praktik di Pengadilan. Jakarta: Kencana.

Subekti. (2003). Pokok-Pokok Hukum Perdata. Jakarta: Intermasa.

Sutan Remy Sjahdeini. (2010). Hukum Kepailitan: Memahami Undang-Undang No. 37 Tahun 2004 Tentang Kepailitan. Jakarta: Pustaka Utama Grafiti.

\section{Jurnal:}

Fani Martiawan. (2014). "Eksistensi Kreditor Separatis Sebagai Pemohon Dalam Perkara Kepailitan". Jurnal Perspektif. Volume XIX Nomor 1 Edisi Januari Tahun 2014. Surabaya: Universitas Wijaya Kusuma Surabaya, h. 6. 